\title{
Intellectual Capital and Knowledge Management Research towards Value Creation. From the Past to the Future
}

\author{
Indra Abeysekera (D)
}

Citation: Abeysekera, Indra. 2021. Intellectual Capital and Knowledge Management Research towards Value Creation. From the Past to the Future Journal of Risk and Financial Management 14: 238. https:// doi.org/10.3390/jrfm14060238

Academic Editor: Ştefan Cristian Gherghina

Received: 15 April 2021

Accepted: 23 May 2021

Published: 28 May 2021

Publisher's Note: MDPI stays neutral with regard to jurisdictional claims in published maps and institutional affiliations.

Copyright: (C) 2021 by the author. Licensee MDPI, Basel, Switzerland. This article is an open access article distributed under the terms and conditions of the Creative Commons Attribution (CC BY) license (https:// creativecommons.org/licenses/by/ $4.0 /)$. Discipline of Accounting and Finance, Charles Darwin University, Darwin, NT 0800, Australia;
indraabeysekera@gmail.com

Abstract: Over the past decade, the body of literature on intellectual capital and knowledge management has grown exponentially, responding to the growing knowledge-based and digital economy. This article reviews the concepts and applications proposed at the initial stages of the launch of these two research paradigms. It then examines the interconnection between the two. The study selected a set of articles on intellectual capital and knowledge management that forward concepts and applications vital to the inception of these two research domains. The analytical review demonstrates that these concepts and applications, although considered separately in research, are interconnected and inform each other. The paper analyzes, discusses, and forms conclusions based on the self-selected literature with informed research knowledge.

Keywords: data; information; intellectual capital; knowledge; knowledge leverage; knowledge management; value creation

\section{Introduction}

Birds tweet, dogs bark, and the wind blows, because it is their nature to do so. However, we cannot understand a dog by its bark alone, a bird by its song, or the wind by its force. There are other attributes these forms display, that are inherent and conditionally developed. Understanding about the attributes makes us understand a dog, a bird, or the wind in its form. Intellectually grasping the complete nature of these forms takes effort, time, and reflection. The forms are both tangible and intangible, and understanding about them is developed in terms of objects and processes. According to Plato, as noted by Welbourne (2014, p. 3), the ultimate knowing of forms surpasses opinions and judgments; they are known fully by finding properties that do not change with time and sense organ perceptions. This knowing is the knowledge. The management literature separates information as knowing-of and knowledge as knowing-how. Rather than knowledge being understood as ultimately leading towards wisdom, an enterprise setting attempts to understand knowledge as perspectives-financial, public policy, legal, and so forth. The financial perspective is vital for enterprises. In an enterprise, intellectual capital is comprehensive knowledge (Augier and Teece 2005). Since knowledge is intangible, it is not measurable in accounting terms. In economics, knowledge is a factor of production; but in accounting, it is an owner's capital. Enterprises do not show the value of knowledge to them on financial statements due to accounting-led measurement difficulties, and hence this value remains hidden.

The search for this hidden value-which plays a pivotal role in firms' value creation but is not shown on the financial position statement (balance sheet)-became a strong motivator for researchers to embark on intellectual capital research to measure, report, and examine its contribution to value creation. Intellectual capital, which is knowledge-based value creation, can indicate the knowledge intensity use and knowledge relevance in a firm (Bhatt 2000). The increasing globalization of trade disrupted firms' reliance on cost leadership alone, as emerging nations benefit from that advantage. Consumerism began to promote varied and wider choices that required firms to focus on organizational knowledge 
and engage in knowledge-intensive activities by acquiring, using, capturing, managing, and leveraging knowledge-colloquially known as knowledge management. Since then, intellectual capital and knowledge management have become vital and inseparable companions for firm value creation.

By November 1993, 12 countries had gained membership in the European Union; starting in January 1994, these countries allowed free movement of people, goods, services, and capital within the block market they had created. Additionally in January 1994, the North American Free Trade Agreement came into operation. These new economic formulations catapulted global trade and intensified competition among firms, causing firms to more aggressively engage in knowledge-intensive activities using knowledge-related assets that offer a competitive advantage. It is no wonder that researchers became keen to explore firms' responses to these evolving and challenging competitive environments.

Figure 1 shows the connection between intellectual capital and knowledge management. Rather than discussing knowledge as assets and liabilities, which would have implications for accounting measurement, knowledge is referred to as a resource, which is an appropriate focus to examine value creation. Knowledge has become the vital new resource for enterprises, for three reasons. First, it is essential for enterprises to create and store knowledge. Second, firms' accumulated knowledge can increase in value through replication of knowledge that is usable and valuable to the enterprise. This is done by sharing, categorizing, and codifying the available knowledge. Third, an enterprise setting can influence the production and leveraging of knowledge through organizational norms, values, and culture. Managing these three aspects together is knowledge management. Managers can choose to embed knowledge resources in objects and processes, and take control and ownership over them. Copyrights, trademarks, trade secrets, and franchised and licensing agreements are legal instruments that assist in protecting future cash inflows arising from knowledge resources (Rowley 1999).

Leveraging

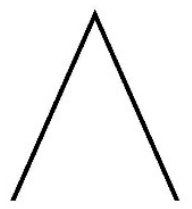

Knowledge management

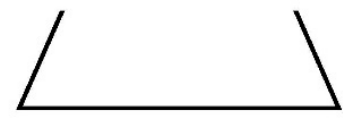

Creating and Setting the

storing
Value creation

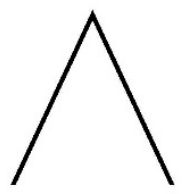

Intellectual capital

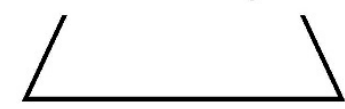

Measure

Report

Figure 1. Nexus between intellectual capital and knowledge management.

Using early literature, this article examines the background factors affecting knowledge management (storing, leveraging, and setting the enterprise environment; see Bhatt 2000; Wong and Aspinwall 2005) and intellectual capital (measuring and reporting), towards firm value creation. The paper also explores the dynamics of managing knowledge, namely, how data becomes information, information becomes knowledge-based assets, and existing knowledge-based assets are leveraged to create more knowledge-based assets and intellectual capital. After review and analysis of more than a decade of articles primarily published in the seven years from 1995 to 2001, the findings point to the common ground between the research paradigms of firms' knowledge and intellectual capital.

The following section presents intellectual capital measurement and reporting issues, and Section 3 presents knowledge and knowledge management. Section 4 discusses 
knowledge capture, followed by Section 5 that examines knowledge transfer. Section 6 discusses knowledge leverage, followed by the Conclusions section.

\section{Intellectual Capital Measurement and Reporting}

This section begins with discussing how organizational knowledge and intellectual capital are measured and reported in traditional accounting. It then describes alternative techniques that have emerged to make up for the shortfalls in current accounting when it comes to comprehensively measuring and reporting knowledge and intellectual capital. This section also introduces economic factors and government policies that have contributed to shaping organizational data, setting the background for later discussion about knowledge management and intellectual capital (Figure 2).

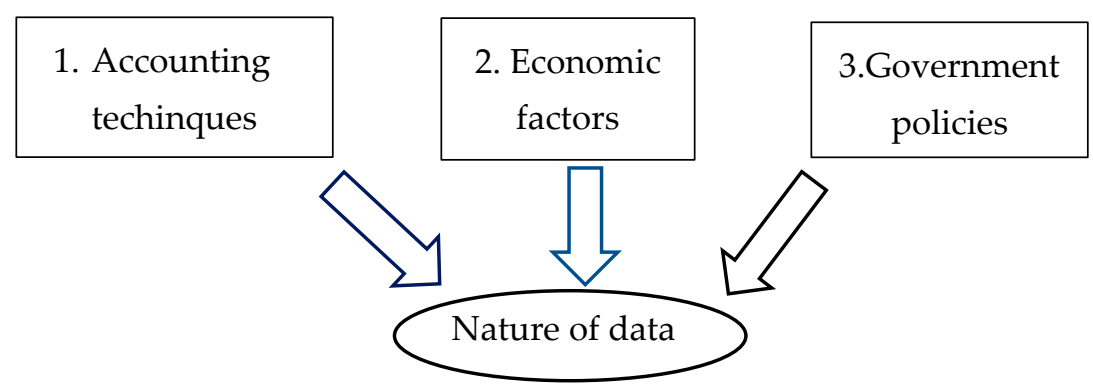

Figure 2. Factors shaping organizational data.

\subsection{The Impact of Traditional Accounting}

The traditional accounting system imposes several limitations in measuring, managing, and reporting intellectual capital. The most notable is writing off intellectual assets as expenses (Backhuijs et al. 1999; IAS38 2021), leading to systematic under-valuation of firms implying relatively adverse liquidity (Boone and Raman 2001; Ronen 2001). The accounting treatment can encourage firms to decrease research and development (R\&D) expenditure to focus on short-term reported financial performance when the marketplace emphasizes lowering cost rather than innovating products and services (Dunk and Kilgore 2001). One way to overcome the anomaly is to partly reverse the previously written off intangibles in the traditional accounting system (Hoegh-Krohn and Knivsfla 2000).

Instead of recognizing knowledge as an asset in their financial reports, firms can add a set of reporting elements to acknowledge forms of capital and claims to capital that firms cannot measure in monetary terms (Thompson 1999). It is valuable to measure these assets even if quantification is less than exact under new measurement rules (Heckmian and Jones 1967). This is because using accounting numbers without values assigned to intangibles like knowledge can become a concern when seeking solutions to management problems (Allen 2001; Anthony 1965, p. 1; Buhner 1997; Copeland 2000; Davies and Waddington 1999; Dearden 1960; Petty and Guthrie 2000, p. 215). A root cause is that the current reporting system does not comprehensively represent objective reality (Petty and Guthrie 2000, pp. 214-15). It also does not offer meaningful indicators of a firm's economic efficiency (Graham and King 2000; Hansson 1997; Zambon and Zan 2000). The current balance sheet records what has been spent and is silent on value-added; it measures only the realization of value rather than the creation of value (Brennan 2001; Romer 1998a).

Although the market value measurement method promotes measuring value creation in a capital market, it does not apply to measurement of intangibles. Accounting standards in most countries only permit the inclusion of purchase goodwill, which represents just a portion of intellectual capital (Van der Meer-Kooistra and Zijlstra 2001). The accounting standards on intangibles may have contributed to a lack of global homogeneity in methods for measuring and disclosing them (Stolowy and Jenny-Cazavan 2001). For example, International Accounting Standard (IAS) 38 specifically prohibits recognizing startup costs, training costs, and advertising costs. It also bans recognition of internally generated goodwill (IAS38 2021). It has not responded well to the current market needs concerning 
measurement and disclosure of intangibles. This failure to react to the contingent nature of accounting measures and reporting can lead to a loss of credibility for the accounting profession (Chapman 1997).

Further, several alternative accounting approaches coexist, making it more complex to verify the multi-dimensional character of knowledge in a firm (Zambon and Zan 2000). The personality profile of accounting professionals also contributes to the narrow professional outlook, although this does seem to be changing to a less conservative profile (Parker 2000).

The gap between book value and market value increasingly questions the relevance of accounting numbers to capital market decision-making (Power 2001; Tollington 2001). According to published accounting standards, the accounting profession is heading towards measuring assets in the marketplace (ASCPA 1999, pp. 6677-782). Technology has enabled businesses to change their approach to providing information to meet users' market needs (Abeysekera 2001a). The expectation is that the annual report of the future will recognize intangible assets as wealth creators, providing forward-looking information (Benjamin 1998, pp. 13-15; Roos et al. 1997, p. 21). The profession is actively debating how to measure, manage, and report intellectual capital and knowledge in a firm, although it has yet to gather the critical mass to achieve significant change (Benjamin 1998, pp. 26-27; Brennan 2001). It is unlikely that we will see considerable change in accounting standards to recognize intellectual capital in financial statements any time soon (Brennan 2001).

\subsection{A Few Other Techniques}

In the current business environment, alternative techniques such as Balanced Scorecard (BSC) and Economic Value Added (EVA) seem to compensate for inadequacies of the traditional accounting system concerning intellectual capital. In the past, Automated Manufacturing Technology highlighted the importance of measuring items that usually are not expressed in monetary terms (Bromwich and Bhimani 1991). The popular Balanced Scorecard (BSC) is a tool to address the issue of reporting intellectual capital (Kaplan and Norton 1992, 1993, 1996). Research has perceived BSC as a tool that drives business performance by linking strategic and short-term planning (Ahn 2001). However, criticism is leveled against the BSC approach for failing to consider people as the only profit generators, as its underlying concept originates from the thinking of the industrial era. Economic Value Added (EVA) is another popular technique; its objective is to maximize Market Value Added (MVA). However, there is only weak evidence that capital market participants respond favorably to adopting residual income-based compensation plans, or that they respond favorably to residual income (Wallace 1996). In fact, earnings generally outperform EVA in relative information content (Biddle et al. 1996). EVA is more a management control system that encourages establishing independent business units and minimum staff, rather than seeking to enhance the productivity and creativity of employees (Mouritsen 1998). A strength of both EVA and MVA is that they do not strictly follow accounting conventions (Young 1997). The criticism against EVA is that it is a measure to account for capital cost, and its focus is on short-term results. However, when comparing knowledge management techniques using BSC and EVA, no comprehensive claim can be made since what is best depends on several factors such as the organization, its people, and its situation (Bontis et al. 1999).

\subsection{Economic Factors}

The expansion of the knowledge-based and service industry have changed two fundamentals in business and economics. Firstly, firms in knowledge-based industries and service-based industries (Sveiby 1997, p. 22) follow the law of increasing returns. In a firm with manufacturing and service or knowledge-based business activity, both the law of diminishing returns and the law of growing returns can co-exist (Arthur 1996). In the knowledge and service industry, it is not clear that earnings figures based on accounting information can explain a firm's stock price (Ball and Brown 1968). Secondly, the process of understanding accounting numbers has shifted from quantitative research to qualitative research and has challenged the notion of capital budgeting to manage outcomes rather 
than processes (Mouck 1998). Further, knowledge-based firms compete on capabilities, requiring strategic investments that may not be justifiable using traditional cost-benefit analysis (Stalk et al. 1992).

\subsection{Government Policies}

Nations have to respond to changes in the economy because such changes impact firms. Governments are faced with competition, the rapid spread of innovative products, electronic commerce, shifts in customer demand, and advancements in science and technology. Nonetheless, it is the responsibility of all governments to provide the right environment for firms to compete and succeed (Teegen 2000); promote commercialized research; and foster entrepreneurial skills (Kinsella and McBrierty 1997; Narula and Dunning 1998). Capabilities are one of the cornerstones of competitiveness in the knowledge-driven economy. In return, governments need to know the return on investment in such intangibles. Although the direct measurement of intangibles is not perfect, they can be measured indirectly using suggested measurement indicators, and a number of measurement models have been constructed for indirect measurement (Dekker and de Hoog 2000). Governments in developing countries have yet to create sophisticated technologies to drive knowledgeeconomy concepts, but can use leapfrog technologies such as telecommunication networks which are becoming available at an affordable price (Malhotra 2000).

\section{Knowledge and Knowledge Management}

\subsection{Definition of Knowledge}

There are a few different philosophical definitions of knowledge, and proponents of each criticize the others for incompleteness (Chisholm 1966, p. 23; Lehrer 1990, p. 3; Morton 2002). The knowledge management literature defines knowledge operationally, and the literature offers several definitions (ASCPA and CMA 1999, p. 69; Davenport et al. 1998; Huseman and Goodman 1999, p. 107; Sveiby 1997, p. 37; Wiig 1993, p. 457). All the operational definitions of knowledge originate from thinking that knowledge is either a process or an object. The process definitions arise from sociology, psychology, and sociology, whereas the object definitions arise from Information Theory. Due to the nature of knowledge, it is unlikely that a formal and uniformly accepted definition will emerge (Martensson 2000).

\subsection{Knowledge Organization and Learning Organization}

Knowledge organization means different things to different people (Huseman and Goodman 1999, pp. 135-56). The literature also defines (Edvinsson and Sullivan 1996; Senge 1990, p. 3) and describes (Gavin 1993) learning organizations. The two learning organization types are determined by who takes the initiative and responsibility for training, whether employees or the firm. Learning firms set the appropriate background to function as learning organizations (Brooking 1996, p. 8) and recognize that most learning occurs through practical job experience (Mayo and Lank 1994, p. 60). They tend to create a form of intellectual capital that is difficult for competitors to imitate (Lennon and Wollin 2001). Learning organizations can act as knowledge creators; the knowledge they create is unique, and can outwit standardized knowledge purchased from the market. For an organization to excel, however, managers should learn to tap into people's commitment and capacity to learn, at all levels in the organization (Aguirre et al. 2001). Several methods are available to measure learning, including learning curves, half-learning curves, questionnaires, and surveys (Gavin 1993; Sadler-Smith and Chaston 2001). Learning theory can be a helpful tool to describe a learning organization's functioning (Wiig 1993, p. 207).

\subsection{Resource-Based Theory of the Firm}

One theory that proposes to describe knowledge-based firms is the resource-based theory. Resources can give rise to competitive advantage (Roos 1998), and the resource- 
based theory argues that firms should have more inimitable and sustainable resources to do this (Barney 1991).

The knowledge-based view is central to the resource-based theory (Conner and Prahalad 1996). This view believes that knowledge resides in individuals, and the primary role of the firm is to apply individuals' knowledge to its goods and services. The knowledge-based view challenges the shareholder value approach, transaction cost economics, and agency theory since knowledge resides in individuals. That personal knowledge is a primary source of advantage in competition (Grant 1996). As a result that the knowledge-based view focuses on value extraction rather than value creation, it is appropriate for firms to focus on commercialized intangible assets such as intellectual properties (Edvinsson and Sullivan 1996).

\subsection{Frameworks to Manage Knowledge}

Figure 3 summarizes the ways data become knowledge. Data, or facts, are the inputs to information where facts are contextualized to make meaning for decision-making, and can originate from learning organizations and knowledge-based organizations. Two key aspects are an information strategy to convert data into information, and a knowledge strategy to convert information into knowledge. A people-centered information strategy aligns when knowledge is managed as processes, and a technology-based information strategy aligns when knowledge is managed as objects. Both process-type and object-type knowledge are considered as knowledge resources.

Knowledge can also depreciate or lose value (Caddy 2001; Caddy et al. 2001) for several reasons, and managing knowledge helps to harness its benefits. Although historically firms have managed knowledge implicitly, effective knowledge management enables firms to harness their utilities in a planned manner (Liebowitz 2001a). Explicit knowledge management strategies are classifiable (Wiig et al. 1997) as objects (Jordan and Jones 1997) and as processes (Huseman and Goodman 1999, pp. 211-17; Von Krogh et al. 2001). However, there is little understanding of how firms create and manage knowledge dynamically (Holsapple and Singh 2001; Nonaka et al. 2000). Assessing knowledge-based systems is still primarily based on anecdote and folklore, and there is a need to impose a scientific foundation (Van Wegen and de Hoog 1999).

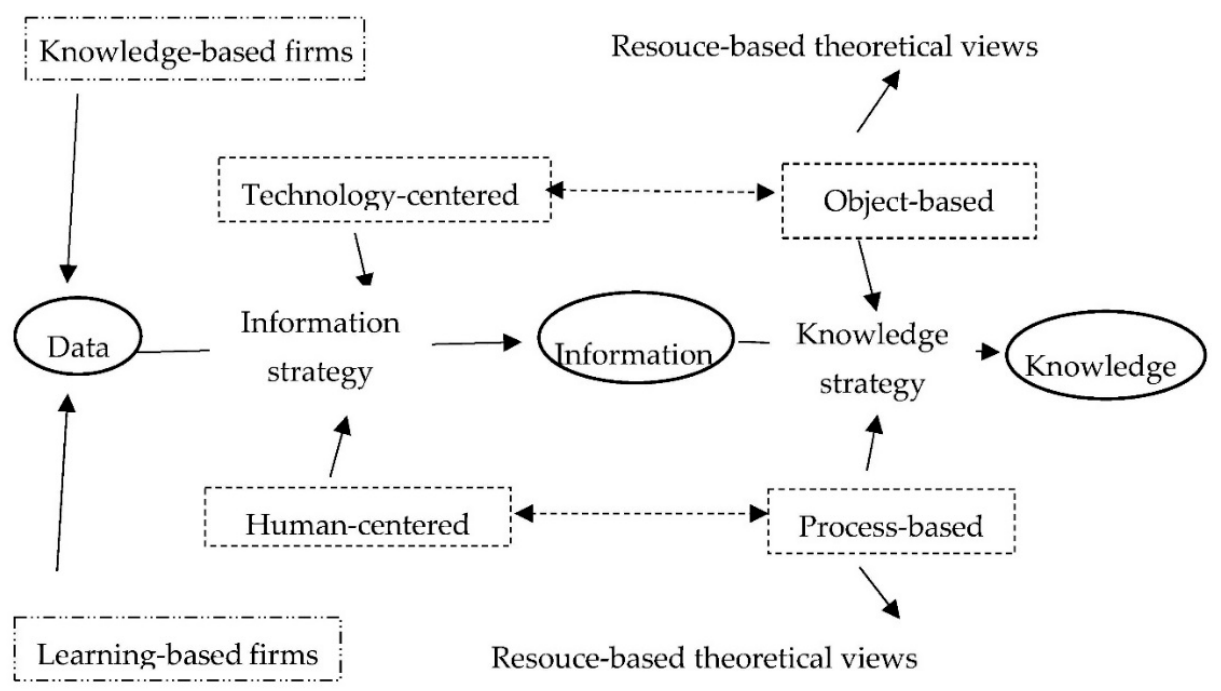

Figure 3. Converting data into knowledge.

Most of the literature on knowledge management discusses private sector firms. From a knowledge perspective, public sector firms have many similarities to the private sector, as well as some notable differences. The public sector has an ever-increasing proportion of knowledge workers and is dependent on intellectual capital for performance (Collier 
2001), but it lacks commitment and capacity to innovate (Senge 1990, p. 15) and is less challenged by the changes outside the work realm. As referred to in Figure 1, this aspect arises from the organizational setting.

\subsection{Definitions of Knowledge Management}

The literature provides several definitions of knowledge management (Brooking 1997; Martinez 1998; Quintas et al. 1997; Sveiby 1998). There is no unified definition because how people use knowledge is different. Definitions here also fall into two classes: knowledge as an object and as a process (Sveiby 1998). Those who consider it as an object take a resourcebased theory view and treat it as a resource contained in the information. Those who believe it is a process treat it as competence and take a strategic or conceptual standpoint. However, it is necessary to manage knowledge both as an object and as a process because processes lead to knowledge objects.

\section{Knowledge Capture}

The starting point in knowledge management is capturing knowledge. The data are translated into information (Schaefer 1998). Information that has meaning becomes knowledge through understanding the patterns (ASCPA and CMA 1999, p. 69). Captured knowledge enables firms to gain more competitive sustainability. Firms can store knowledge by treating it either as an object or as a process. The tool commonly used to capture knowledge as an object is information technology. The technology enables knowledge to be captured by mapping it (Davenport and Prusak 1998, pp. 72-87). In this respect, this article reviews expert systems, database technology, web-based applications, and interactive online decision support systems.

\subsection{Technology: Expert Systems}

Expert systems (knowledge-based systems) are a better alternative to statistical models employed in the past (Ragothaman et al. 1995), and most of them are object-oriented (Devedzic 1999). Expert systems are very effective when the problem space is well defined and limited (Malhotra 2001). They constitute a valuable tool to disseminate expertise in the workforce (Brooking 1996, p. 52). Their primary function is to convert data into knowledge (Fernandez-Breis and Martinez-Bejar 2000). Firms obtain these preliminary data from human experts through protocol analysis, checklists, and structured interviews (Armoni 1995; Wooten and Rowley 1995). Interfaces such as natural language and speech are possible techniques firms can apply to managing knowledge in the future (Liebowitz 2001a). Expert systems can also induct rules from data in the knowledge base, enabling them to make better decisions because expert systems can refine human skills and knowledge as intelligent systems.

Firms can use intelligent systems to select the right employees for training and avoid over- or under-training (Ntuen and Chestnut 1995). Firms can also computerize decision aids by incorporating expert systems to acquire more knowledge (Rose and Wolfe 2000). While providing solutions to the problem, expert systems techniques can also logically scrutinize the domain knowledge, gaps, and inconsistencies (Taylor et al. 1995). Most expert systems elicit knowledge from individual experts, and eliciting their understanding is a labor-intensive activity (Liebowitz 2001a). Therefore, knowledge engineers should have excellent technical expertise to construct a sound expert system (Wooten and Rowley 1995). Graphical modeling is a user-friendly interface to acquire domain experts' knowledge due to minimal keyboard input (Walczak 1998). Since neural networks undergo training by feeding many cases into the system, they require little human intervention and sort noisy data (Liebowitz 2001b). Multi-disciplinary experts are critical to knowledge work but using them requires addressing several issues related to their management. The use of multiple expert systems experts is still in its infancy (Medsker et al. 1995). Networking many intelligent systems to access a more extensive knowledge base is a suggested improvement (Ohsuga 1995). Firms must supplement structured knowledge in expert systems with 
unstructured knowledge (examples are notes, observations, comments) to add value to the knowledge base (Count 1998). Other knowledge-based technologies become important in that direction.

\subsection{Technology: Databases}

The database is one of the essential knowledge management tools but is among the most ignored (Brown and Duguid 2000). Examples are Lotus notes (Davenport and Prusak 1998, p. 77) and Oracle's web application server. This technology can access a large volume of data while safeguarding confidentiality (Vanoirbeek et al. 2000) and can be organized to disseminate information through the internet and intranet on a real-time basis. Accounting resource packages with a human resource module such as PeopleSoft and SAP also can link simple generic knowledge categories to employee compensation (Davenport and Prusak 1998, p. 77).

\subsection{Technology: Web-Based Applications}

Most database structures and information technology can capture only a fraction of knowledge. As a result, the emphasis has shifted towards information and communication technologies (Quintas et al. 1997). The majority of web-based applications conform to a database approach so that the user can generate HTML documents dynamically (Vanoirbeek et al. 2000). Firms must examine the possibility of converting programs written in other languages (such as $\mathrm{C}++$ ) to Java since Java is the current leading-edge method to develop interactive web applications (Walczak 1998).

\subsection{Technology: Interactive Online Decisions Support Systems}

Interactive online support systems can overcome weaknesses in text-based data by verbalizing and accessing several types of experts online around the world to make better decisions (Baupin and Zreik 2000).

\subsection{Knowledge-Capture Processes}

The notable difference between knowledge-capture processes and reengineering processes is that knowledge capture processes use a bottom-up approach. These processes assume that firms cannot identify value-creating activities to compete in an unpredictable environment to maximize identification; they have to balance structured and unstructured processes (Brown and Duguid 2000). The firm should identify processes that facilitate knowledge to foster new understanding and sustain competitive advantage by limiting the competitors' ability to create knowledge (Stonehouse et al. 2001).

The firm can maintain its competitive advantage by using knowledge inhibitor processes in several ways. These include influencing the timing of releasing potentially helpful information, selectively releasing information, developing innovative technological and organizational knowledge systems that are difficult to replicate, and creating financial barriers to access key relevant information (Stonehouse et al. 2001). Knowledge capture processes are applicable within the firm (Davenport and Prusak 1998, pp. 52-67; Richards et al. 1998). For example, informal, self-organizing networks within the firm (Goleman 1995, p. 162) may become formalized over time (Davenport and Prusak 1998, pp. 5267). In addition, most firms apply a strategy to acquire knowledge from outside the firm (Jordan and Jones 1997) through acquisitions (Davenport and Prusak 1998, pp. 53-56), joint ventures, and mergers (Demirbag and Mirza 2000).

Management processes that are appropriate to one organization may not apply to another. Reviewing these processes is key to knowledge leverage because management processes are achieved through and by people. People's involvement in the processes is the crux of leveraging knowledge (Abeysekera 2001b, p. 4). 


\section{Knowledge Transfer}

\subsection{Role of Information}

Today's increase in information is partly due to R\&D activities and the powerful technologies that generate them. The more uncertain the task, the more information that needs to be processed to execute a job to achieve a given performance level (Galbraith 1977, pp. 6-7). The information communicates data in a broader sense about the environment (Roos et al. 1997, p. 25) and comes in various text, audio, and visual forms (Davenport and Prusak 1998, pp. 2-5). The value of information may vary from one firm to another since some firms sell knowledge as a package that is information-driven. Others sell understanding that is also a knowledge process (Sveiby 1997, p. 24). In large firms, technology is the key to managing information on the core product of knowledge and designing the information flow to share it evolutionarily. Since knowledge is transferred in the form of information, the quality of knowledge depends on the accuracy and appropriateness of that information (Dewett and Jones 2001).

\subsection{Information Strategy}

An information strategy should have some level of a human-centered approach (Davenport 1994; Davenport et al. 1992; Linowes et al. 2000). Employees must learn to communicate face to face before planning to make the most out of electronic communication. Staff members' willingness to use information depends on the level of involvement and the level of trust they have in those who designed it. The amount of investment in information technology depends on the strategy used by a firm to share knowledge among people (Hansen et al. 1999). The firm should look at its use of information, business practices, and processes that generate data and manage information politics to harness its benefits (Davenport et al. 1992; The Economist Intelligence Unit 1998, p. 11). Computer technology facilitates managing knowledge, but knowledge management is not dependent on information technology (Guthrie and Petty 2000; Teece 2000) because it comprises more than using information technology tools (Teece 2000).

\section{Knowledge Leverage}

There are various ways to organize knowledge. Unlike manufacturing processes, knowledge management processes must deal with more unstructured data. Bhatt (2000) proposed a knowledge management framework to make the knowledge development cycle more effective. This cycle has four dimensions: knowledge creation, knowledge adoption, knowledge distribution, and knowledge review and revision. Bhatt proposed implementing different strategies for the four dimensions.

This paper presents a knowledge management framework that integrates intellectual capital because its focus is organizational value creation. Figure 4 outlines value creation using knowledge as a process and an object. The value-adding potential of a company (Knowledge Value factor) depends on the positive relationship between service level and knowledge intensity (Tissen et al. 2000, pp. 8-9). The relationship is enhanced by mangers taking note of knowledge types in their strategic approaches. 


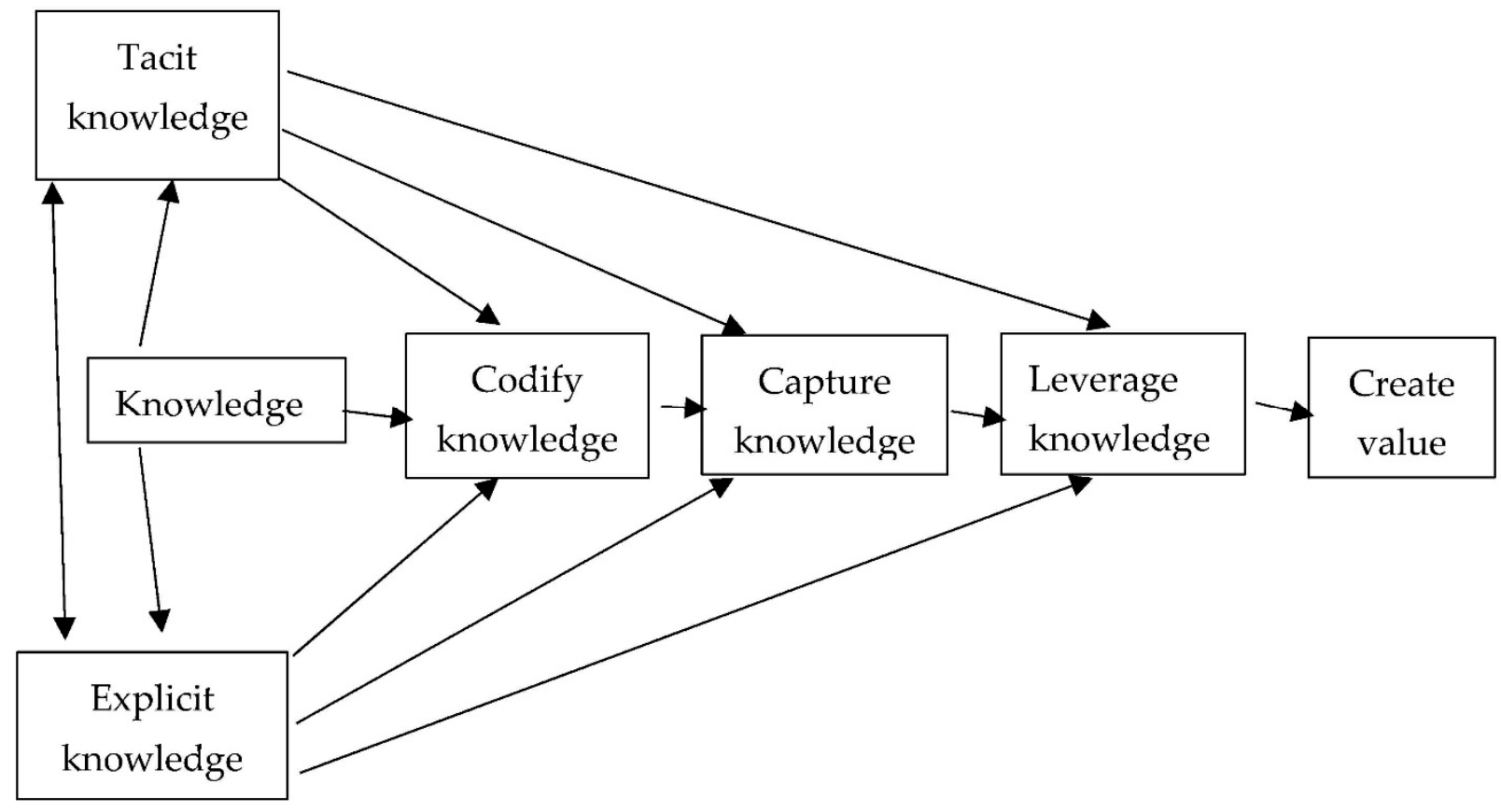

Figure 4. From knowledge to value creation.

\subsection{Knowledge Types}

Knowledge held in people's minds is internal knowledge (Wiig 1993, pp. 74, 233), and is either tacit (Edvinsson and Sullivan 1996) or explicit (Demarest 1997). Codified knowledge (Edvinsson and Sullivan 1996) is a subset of explicit knowledge. Codifying corporate knowledge is an immense task and a futile attempt (Davenport and Prusak 1998, p. 68). Implicit knowledge is the knowledge that is understood without consciously realizing it. It is embedded in technology, operating, and management practices, or is documented with implied conclusions, anecdotes, and narratives of results from research papers and textbooks. Firms must necessarily analyze where data arise from to extract the relevant knowledge. The first step is to assimilate implicit knowledge to translate it into tacit knowledge (Wiig 1993, pp. 74, 233).

The literature interprets tacit knowledge in several ways, as demonstrated by Hori (2000), Wiig (1993, pp. 74, 233), Nonaka (1991), and Noh et al. (2000). Hori (2000) states that it is not possible to verbalize tacit knowledge. Tacit knowledge has three parts. First, the skill is learned only by daily professional training; second, tacit knowledge is acquired partially by translating verbal knowledge into a perception-action link. Third, the nebulous part is not verbalizable because it is new and premature (Hori 2000). Wiig (1993, pp. 74, 233) interprets tacit knowledge as that personal knowledge inaccessible to the conscious mind but that can be used or recalled automatically without much thinking (Liebowitz 2001a). That knowledge is drawn upon to carry out tasks known well to the employee. "Know-how" is mostly tacit knowledge (Wiig 1993, pp. 74, 233). According to Nonaka (1991), tacit knowledge has two parts. One part is hard to pin down technical skills known as know-how, mental models, and beliefs. The other part is the not easily articulated perspectives, known as the cognitive dimension. Metaphors, analogies, and models assist in translating concepts through consistent, systematic logic. This approach has shaped the organizational design of knowledge firms in Japan.

An organization's structure must overlap its information, business activities, and managerial responsibilities to encourage dialogue and communication and spread new explicit knowledge. This knowledge transfer can be done by strategic rotation of employees, two or more groups of employees pursuing the same project, free access to firm information, and continually challenging employees to re-examine what they take for granted (Nonaka 
1991). Noh et al. (2000) state that tacit knowledge management involves four parts: formalizing knowledge through cognitive maps, reusing knowledge by storing multiple cognitive maps as cases, solving problems by retrieving mental map cases, and situational applications.

The literature has focused chiefly on explicit knowledge rather than tacit knowledge (Noh et al. 2000). Explicit knowledge is readily available to conscious minds and can be readily explained or examined, such as in documents, procedures, and computer programs. It can be more easily documented (Liebowitz 2001a). Explicit knowledge is accessible in the form of shared expertise or public knowledge. By making explicit knowledge formal, it becomes readily distributable, embodied in either raw materials, products and services, machinery and mechanisms, organizational practices and processes, or "soft" cultural or organizational values (for example, open-door policies). Commercial firms' explicit knowledge is classifiable as behavioral directives, predictive models, algorithms and heuristic logic models, and performance prescriptions (Demarest 1997).

When tacit knowledge is codified to make it explicit knowledge, those who need that knowledge can access it when in need. It also helps organizations assert their ownership (Edvinsson and Sullivan 1996) and facilitates reuse (Romer 1998b). However, constructing and applying organizational memory is still in a very early stage (Studer et al. 1998). There are vast differences between industries in their approach to knowledge codification. For example, service industries are more concerned with incorporating best practice into processes, while the engineering industry attempts to codify knowledge as objects.

\subsection{Knowledge Levels}

Knowledge leverage takes place at four levels: tacit-to-tacit, tacit-to-explicit, explicitto-tacit, and explicit to-explicit (Sveiby 1997). All four of these levels exist in a firm (Nonaka 1991). Some argue that tacit-to-tacit-for example, informal networks—is a powerful way to achieve knowledge leverage (Goleman 1995, p. 162). As an organization drives towards abandoning hierarchical structures, managers need to rely less on authority and more on relationships in informal networks (Krackhardt and Hanson 1993). Others argue that tacitto-explicit is the primary way to increase available knowledge throughout the firm. Most Western managers think that valuable knowledge is quantifiable, codified, and follows universal principles; they see the firm as a machine to process information. In contrast, Japanese firms believe that knowledge creation occurs by tapping into tacit knowledge, insights, intuitions, and employees' hunches (Nonaka 1991).

Both tacit and explicit knowledge are complementary and essential for knowledge creation (Nonaka et al. 2000). Firms in the West are increasingly sharing this approach (Brown and Duguid 2000). Various models suggest bringing tacit knowledge to the surface, and most of them are constructed around the concept of a learning organization.

Figure 4 provides a framework to convert knowledge into value creation. The two knowledge types, tacit and explicit, are not only part of the knowledge pool but also interact with each other. It is important for organizations to codify and capture them to store this knowledge for wider use. The knowledge is then retained within the organization even as staff enter and exit employment. Captured knowledge is available to share among others, thereby enhancing organizational capability, using and reusing knowledge, and synthesizing new knowledge by reconfiguring the available knowledge.

\subsection{Knowledge Leverage Strategies}

Personalization and codification are two strategies used by firms to share knowledge throughout the firm. The type of strategy of a firm depends on how the firm serves its clients, the business's economics, the people it hires (Hansen et al. 1999), and the type of industry in which the firm operates. Typically, an organization needs a mix of two strategies (Liebowitz 2001a). However, the wrong approach can undermine the organization's knowledge leverage strategy (Hansen et al. 1999). 


\section{Conclusions}

A firm should meet basic requirements to develop an intellectual capital system (Roos and Roos 1997; Roos et al. 1997, p. 77). Intellectual capital literature has elaborated subsystems specifying internal capital—intellectual capital embedded in the firm structure; external capital-intellectual capital embedded in partnership with stakeholders; and human capital-intellectual capital embedded in staff members. In this trichotomous classification, human capital enables value creation using internal capital and external capital.

Figure 5 shows the connection between intellectual capital and knowledge management that leads to value creation in firms. Intellectual capital is a vital component of accessible but hidden capital in organizations. Intellectual capital arises within the firm's internal capital such as firm culture and legal instruments that enable knowledge to be embedded (copyrights and patents). It also arises by interacting with business partners such as customers and suppliers through good relations. Firms can build loyal customers who repeatedly purchase products and services, and suppliers who offer competitive prices and reliability deliver the agreed products and services to the firm. Intellectual capital comprises a gamut of knowledge resources that represent the total organizational knowledge. This knowledge requires management for use, reuse, replenishment, and additions. Managed knowledge is available to use in knowledge processes and knowledge objects, and to embed in products and services. Managed knowledge requires human intervention to be leveraged, and to create value for the organization. People's decisions on where, when, and how to embed knowledge in products and services is vital to enhancing value creation.

Figure 6 shows the contemporary situation where an enormous amount of data relevant to the enterprise is generated within and outside the firm. As shown in Figure 1, various forces shape the nature of data and data accessibility. Figure 2 shows that firm strategies help firms convert data into information and then knowledge. Figure 3 depicts that knowledge is captured and leveraged to create firm value. Figure 4 shows that captured firm knowledge becomes intellectual capital, which is part of the total accessible capital in a firm. In a knowledge-based firm, intellectual capital constitutes a more significant proportion of that capital. The total accessible capital is managed and leveraged to create firm value. The human capital component of intellectual capital plays a vital role with capabilities and competencies. Data, information, knowledge, managed knowledge, leveraged knowledge, and value created comprise the firm's resources. These become unique resources of the firm shaped by firm characteristics, difficult for others to copy to create firm value, and integrated into the intellectual capital base. With the immediate help of human capital comprising capabilities and competencies, the intellectual capital base enables the transformation of data, information, knowledge, managed knowledge, leveraged knowledge, and value created back into data.

Embedding knowledge as objects and processes in products and services enables firms to create organizational value by becoming more efficient, economical, and effective. It also makes it possible increase accuracy so that there are less warranty claims and returns, and there is greater security in resources. Value creation occurs with the economical, efficient, and effective use of resources. This effectiveness can arise through timely, focused resources that meet the enterprise's operational and strategic aims and objectives. Firms can use the data obtained through value creation from business partners such as customers, suppliers, employees, and the government through knowledge-based value chain analysis. These relevant new data add to existing relevant data to continue to create future firm value. Knowledge management connects the accessible capital with value creation. Intellectual capital plays the role of an enabler for knowledge management to do this. In the increasingly expanding global knowledge-based economy, knowledge management and intellectual capital have become inseparable partners in enterprise value creation. 


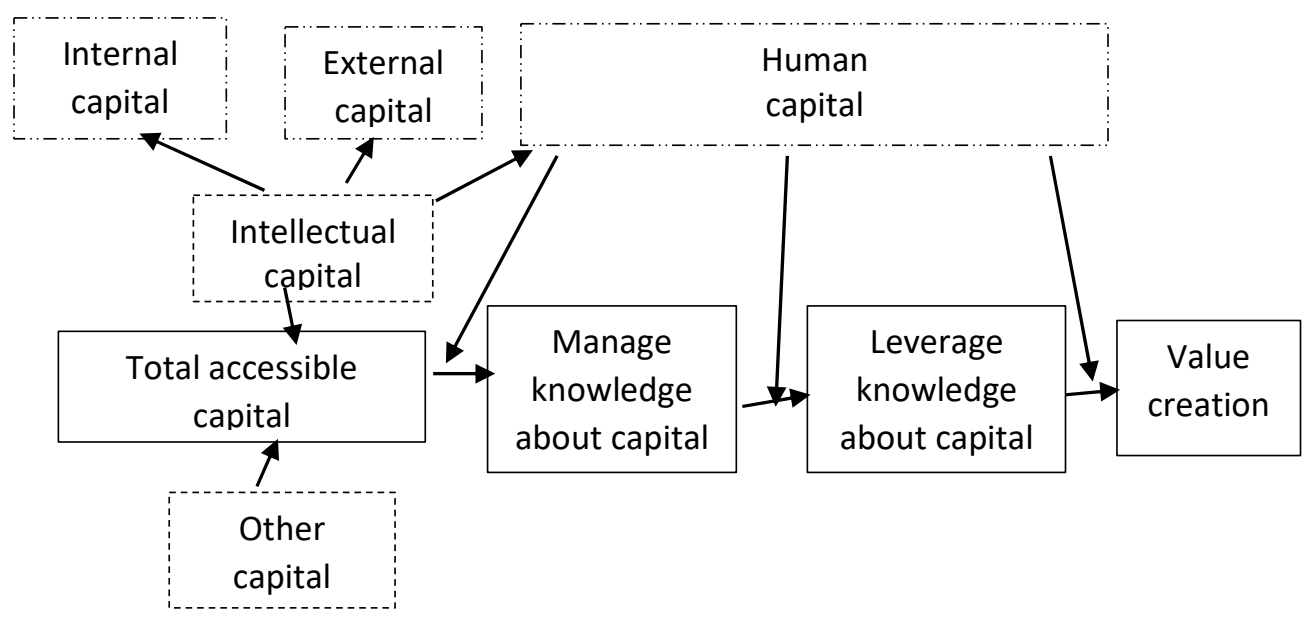

Figure 5. The nexus between intellectual capital and knowledge management in firms.

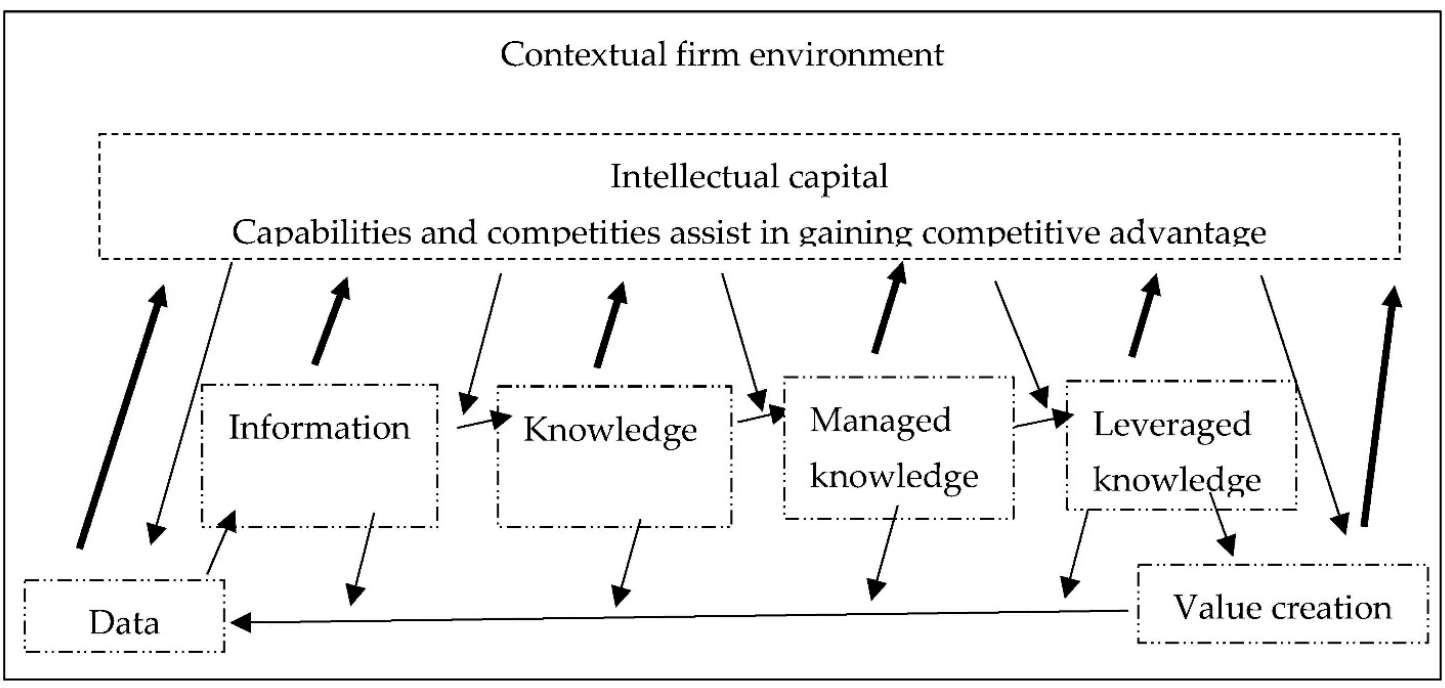

Figure 6. Data to value creation.

Theoretical implications: This review facilitates the posing of research questions in various ways. For instance, Alavi and Leidner (2001) defined knowledge management systems from a technological standpoint as an information-technology-based system supporting different phases of knowledge management. Research can thus be undertaken to analyze across two knowledge dimensions. The degree of formalizing knowledge (tacit to explicit) is epistemological, and the degree of sharing (individual to group, and closed to open) is ontological (Centobelli et al. 2019; Nonaka 1994).

Given that the focus of this review is the connection between knowledge management and intellectual capital, it presents the following three research propositions. It is evident that human capital plays a more vital role than before in a digitized firm. Gleaning from Figure 5, a study can examine the influence of human capital on value creation while moderating the following relationships: total accessible capital and knowledge management about capital; managing knowledge about capital and leveraging knowledge about capital; and leveraging knowledge about capital and value creation. Secondly, gleaning from Figure 6, a study can examine the reverse influence of value creation on data and intellectual capital. Thirdly, based on Figure 6, a study can look at the influence of intellectual capital on value creation with intellectual capital having a moderating relationship between the following: information and knowledge, knowledge and managed knowledge, and managed knowledge and leveraged knowledge. 
Regulatory implications: Governments now have the task of building a capable workforce to participate in the digital economy and to encourage organizations to digitize processes and objects in producing goods and services with a focus on cybersecurity. Information and communication technologies have a greater role to play as objects of knowledge management. The COVID-19 pandemic has provided a jumpstart during the countries' lockdown periods to appreciate and embrace the digital economic environment (Australian Government 2021). These regulatory implications have taken a new direction to situate the connection between intellectual capital and knowledge management for value creation. The control and ownership of intellectual capital items of firms also has changed with the digital economy. There are knowledge-based intellectual capital items such as software-led processes and systems developed within the firm. These can become vital assets for firm value creation. Measuring their costs and recognizing them as assets rather than expenses requires more pointed attention. Owning, controlling, renting cloud spaces for value creation is another intellectual capital item in the digital economy requiring attention as to the treatment of them as assets and expenses.

Practical implications: Wiig (1997) noted that the approach to knowledge management can change with new economic environments. The world economy has now become a digital economy. The digital economy has increased the demand on the inseparability of knowledge management and intellectual capital and practical implications are conditional upon the pervasiveness of the digital platform. An enterprise in a digitized economy uses business intelligence which is built upon database management systems, intelligence systems, and enterprise resource planning systems. A digitized environment in an organization generates and provides access to data within and outside the firm. The databases are migrating from relational to object-oriented, broadening the types of data stored and relevant accessible data. Enterprise resource planning systems integrate functions and facilitate sharing relevant data across functions. There are several intelligent systems to assist with making accurate decisions. These include executive support, decision support, executive information, group support, experts, knowledge management systems, neural networks, intelligent agents, and data warehouses (Gelinas et al. 2018, pp. 140-221). Business intelligence is built using data as a basic ingredient, converting it into information, and then to knowledge. Firms now must conduct knowledge management in a digital environment with an emphasis on value creation.

Funding: This research received no external funding.

Institutional Review Board Statement: Not applicable.

Informed Consent Statement: Not applicable.

Data Availability Statement: This article does not include data for reuse.

Conflicts of Interest: The author declares no conflict of interest.

\section{References}

Abeysekera, Indra. 2001a. Intellectual Capital and Knowledge Management: Two Sides of the Same Coin. Economic Review 27: 31-33. Abeysekera, Indra. 2001b. Leveraging knowledge for short, long term profit. In The Sunday Business Times. Colombo: Wijeya Publications.

Aguirre, Jose Luis, R. Brena, and Francisco J. Cantu-Ortiz. 2001. Multiagent-Based Knowledge Networks. Expert Systems Applications 20: 65-75. [CrossRef]

Ahn, Heinz. 2001. Applying the Balanced Scorecard Concept: An Experience Report. Long Range Planning 34: 441-61. [CrossRef]

Alavi, Mariyam, and DorothyE. Leidner. 2001. Review: Knowledge Management and Knowledge Management Systems: Conceptual Foundations and Research Issues. MIS Quarterly: Management Information Systems 25: 107-36. [CrossRef]

Allen, David. 2001. Hard Currency. Financial Management. Available online: https://www.thefreelibrary.com/Hard+currency.-a078 965311 (accessed on 9 April 2021).

Anthony, Ro N. 1965. Management Accounting Principles. Homewood: Richard D. Irwin Inc.

Armoni, Adi. 1995. Knowledge Acquisition for Medical Diagnosis Systems. Knowledge-Based Systems 8: 223-26. [CrossRef]

Arthur, W. Brian. 1996. Increasing Returns and the New World of Business. Harvard Business Review 74: 100-9. [PubMed] 
ASCPA (Australian Society of Certified Practising Accountants). 1999. Members Handbook. Update No. 58. Chatswood: Butterworths Australia, vols. 1, 4 .

ASCPA (Australian Society of CPAs), and CMA (The Society of Management Accountants of Canada). 1999. Knowledge Management: Issues, Practice and Innovation. Melbourne: Australian Society of Certified Practising Accountants.

Augier, Mie, and David Teece. 2005. An Economics Perspective on Intellectual Capital. In Perspectives on Intellectual Capital. Edited by Bernard Marr. Alpharetta: Elsevier.

Australian Government. 2021. Participating in the Digital Economy; Department of Industry Sciences, and Industry Resources. Available online: https: / / www.industry.gov.au/policies-and-initiatives/participating-in-the-digital-economy (accessed on 11 May 2021).

Backhuijs, J. B., W. G. M. Holterman, S. Holterman, R. P. M. Overgoor, and S. M. Zijlstra. 1999. Reporting on Intangible Assets. Paper presented at the OECD Symposium on Measuring and Reporting of Intellectual Capital, Amsterdam, The Netherlands, June 9-11; Available online: https://www.oecd.org/industry/ind/1947807.pdf (accessed on 9 April 2021).

Ball, Ray, and Philip Brown. 1968. An Empirical Evaluation of Accounting Numbers. Journal of Accounting Research 6: 159-77. [CrossRef]

Barney, Jay. 1991. Firm Resources and Sustained Competitive Advantage. Journal of Management 17: 99-120. [CrossRef]

Baupin, N., and Khaldoun Zreik. 2000. Remote Decision Support System: A Distributed Information Management System. KnowledgeBased Systems 13: 37-46. [CrossRef]

Benjamin, Alan. 1998. Prototype plc: The 21st Century Annual Report. The 21st Century Annual Report, Corporate Governance. London: Institute of Chartered Accountants of England \& Wales, Available online: https://www.icaew.com/-/media/corporate/ files / technical / financial-reporting/information-for-better-markets/ifbm-reports/new-reporting-models-for-business-2010 -version.ashx (accessed on 9 April 2021).

Bhatt, Ganesh D. 2000. Organizing Knowledge in the Knowledge Development Cycle. Journal of Knowledge Management 4: 15-26. [CrossRef]

Biddle, Gary C., Robert M. Bowen, and James S. Wallace. 1996. Does EVA Beat Earnings? Evidence on Associations with Sock Returns and Firm Values. Journal of Accounting E Economics 24: 301-36. [CrossRef]

Bontis, Nick, Nicola C. Dragonetti, Kristine Jacobsen, and Goran Roos. 1999. A Review of the Tools Available to Measure and Manage Intangible Resources. European Management Journal 17: 391-402. [CrossRef]

Boone, Jeff P., and Krishnamurthy K. Raman. 2001. Off-Balance Sheet R\&D Assets and Market Liquidity. Journal of Accounting and Public Policy 20: 97-128. [CrossRef]

Brennan, Naimh. 2001. Reporting Intellectual Capital in Annual Reports: Evidence from Ireland. Accounting, Auditing and Accountability Journal 14: 423-36. [CrossRef]

Bromwich, Michael, and Alnoor Bhimani. 1991. Strategic Investment Appraisal. Management Accounting 72: 45-48.

Brooking, Annie. 1996. Intellectual Capital, Core Assets for the Third Millennium Enterprise. London: International Thomson Business.

Brooking, Annie. 1997. The Management of Intellectual Capital. Long Range Planning 30: 364-65. [CrossRef]

Brown, John Seely, and Paul Duguid. 2000. Balancing Act: How to Capture Knowledge Without Killing It. Harvard Business Review 78: 73-80.

Buhner, Rolf. 1997. Increasing Shareholder Value through Human Asset Management. Long Range Planning 30: 710-17. [CrossRef]

Caddy, Ian, James Guthrie, and Richard Petty. 2001. Managing orphan knowledge: Current Australasian best practice. Journal of Intellectual Capital 2: 384-97. [CrossRef]

Caddy, Ian. 2001. Orphan knowledge: The new challenge for knowledge management. Journal of Intellectual Capital 2: $236-45$. [CrossRef]

Centobelli, Piera, Roberto Cerchione, and Emilio Esposito. 2019. Efficiency and Effectiveness of Knowledge Management Systems in SMEs. Production Planning \& Control 30: 779-91. [CrossRef]

Chapman, Christopher S. 1997. Reflections on a contingent view of accounting. Accounting, Organizations and Society 22: 189-205. [CrossRef]

Chisholm, Roderick M. 1966. Theory of Knowledge. Hoboken: Prentice Hall Inc.

Collier, Paul M. 2001. Valuing Intellectual Capacity in the Police. Accounting, Auditing E Accountability Journal 14: $437-55$.

Conner, Kathleen R., and Coimbatore Krishnarao. Prahalad. 1996. A Resource-Based Theory of the Firm: Knowledge versus Opportunism. Organization Science 7: 477-501. [CrossRef]

Copeland, Tom. 2000. Cutting Costs without Drawing Blood. Harvard Business Review 78: 155-64. [PubMed]

Count, Aw W. 1998. Issues for Integrating Knowledge in New Product Development: Reflections from an Empirical Study. Knowledge Based Systems 11: 391-98. [CrossRef]

Davenport, Thomas H. 1994. Saving IT Soul: Human-Centred Information Management. Harvard Business Review 72: 119-31.

Davenport, Thomas H., and Laurence Prusak. 1998. Working Knowledge, How Organizations Manage What They Know. Boston: Harvard Business School Press.

Davenport, Thomas H., David W. De Long, and Michael C. Beers. 1998. Successful Knowledge Management Projects. Sloan Management Review 39: 43-57.

Davenport, Thomas H., Robert G. Eccles, and Laurence Prusak. 1992. Information Politics. Sloan Management Review 15: 53-65. Available online: https://sloanreview.mit.edu/article/information-politics/ (accessed on 10 April 2021).

Davies, Jan, and Alan Waddington. 1999. The Management and Measurement of Intellectual Capital. Management Accounting 77: 34.

Dearden, John. 1960. Problem in Decentralized Profit Responsibility. Harvard Business Review 38: 79-86. 
Dekker, Rijkje, and Robert de Hoog. 2000. The Monetary Value of Knowledge Assets: A Micro Approach. Expert Systems with Applications 18: 111-24. [CrossRef]

Demarest, Marc. 1997. Understanding Knowledge Management. Long Range Planning 30: 374-84. [CrossRef]

Demirbag, Mehmet, and Hafiz Mirza. 2000. Factors Affecting International Joint Venture Success: An Empirical Analysis of ForeignLocal Partner Relationships and Performance in Joint Venture in Turkey. International Business Review 9: 1-35. [CrossRef]

Devedzic, Vladan. 1999. A Survey of Modern Knowledge Modeling Techniques. Expert Systems with Applications 17: 275-94. [CrossRef]

Dewett, Todd, and Gareth R. Jones. 2001. The Role of Information Technology in the Organisation: A Review, Model, and Assessment. Journal of Management 27: 313-46. [CrossRef]

Dunk, Alan S., and Alan Kilgore. 2001. Short-Term R\&D Bias, Competition on Cost Rather Than Innovation, and Time to Market. Scandinavian Journal of Management 17: 409-20. [CrossRef]

Edvinsson, Leif, and Patrick Sullivan. 1996. Developing a Model for Managing Intellectual Capital. European Management Journal 14: 356-64. [CrossRef]

Fernandez-Breis, Jesualdo Tomas, and Rodrigo Martinez-Bejar. 2000. A Cooperative Tool for Facilitating Knowledge Management. Expert Systems with Applications 18: 315-30. [CrossRef]

Galbraith, Jay R. 1977. Organization Design. Philippines: Addison-Wesley Publishing, Inc.

Gavin, David A. 1993. Building a Learning Organization. Harvard Business Review 71: 78-91.

Gelinas, Ulric J., Jr., Richard B. Dull, and Patrick R. Wheeler. 2018. Accounting Information Systems, 11th ed. Victoria: Cengage Learning Australia.

Goleman, Daniel. 1995. Emotional Intelligence. New York: Bantam Books.

Graham, Roger C., and Raymond D. King. 2000. Accounting Practices and the Market Valuation of Accounting Numbers: Evidence from Indonesia, Korea, Malaysia, the Philippines, Taiwan, and Thailand. The International Journal of Accounting 35: 445-70. [CrossRef]

Grant, Robert M. 1996. Towards a Knowledge-Based Theory of the Firm. Strategic Management Journal 17: 109-22. [CrossRef]

Guthrie, James, and Richard Petty. 2000. Intellectual capital: Australian annual reporting practices. Journal of Intellectual Capital 1: 241-51. [CrossRef]

Hansen, Morten T., N. Nitin Nohria, and Thomas J. Tierney. 1999. What's Your Strategy for Managing Knowledge. Harvard Business Review 77: 106-16.

Hansson, Bo. 1997. Personnel Investments and Abnormal Return: Knowledge-Based Firms and Human Resource Accounting. Journal of Human Resource Costing and Accounting 2: 9-29. [CrossRef]

Heckmian, James S., and Curtis H. Jones. 1967. Put People on Your Balance Sheet. Harvard Business Review 45: 105-13.

Hoegh-Krohn, Nils E. Joachim, and Kjel Henry Knivsfla. 2000. Accounting for Intangible Assets in Scandinavia, the UK, the US, and by the IASC: Challenges and a Solution. The International Journal of Accounting 35: 243-65. [CrossRef]

Holsapple, Clyde W., and Meenu Singh. 2001. The Knowledge Chain Model: Activities for Competitiveness. Expert Systems with Applications 20: 77-98. [CrossRef]

Hori, K. 2000. An Ontology of Strategic Knowledge: Key Concepts and Applications. Knowledge-Based Systems 13: 369-74. [CrossRef]

Huseman, Richard C., and Jon P. Goodman. 1999. Leading with Knowledge. The Nature of Competition in the 21st Century. Thousand Oaks: Sage.

IAS38 (International Financial Reporting Standards 38). 2021. Intangible Assets. Available online: https://www.ifrs.org/issuedstandards/list-of-standards/ias-38-intangible-assets/\#about (accessed on 27 May 2021).

Jordan, Jordan, and Penelope Jones. 1997. Assessing Your Company's Knowledge Management Style. Long Range Planning 30: 392-98. [CrossRef]

Kaplan, Robert S., and David P. Norton. 1992. The Balanced Scorecard-Measures That Drive Performance. Harvard Business Review 70: 71-79.

Kaplan, Robert S., and David P. Norton. 1993. Putting the Balanced Scorecard to Work. Harvard Business Review 71: $134-47$.

Kaplan, Robert S., and David P. Norton. 1996. Using the Balanced Scorecard as a Strategic Management System. Harvard Business Review 74: 75-85.

Kinsella, Ray, and Vincent McBrierty. 1997. Campus Companies and the Emerging Techno-Academic Paradigm: The Irish Experience. Technovation 17: 245-51. [CrossRef]

Krackhardt, David, and Jeffrey R. Hanson. 1993. Informed Networks: The Company Behind the Chart. Harvard Business Review 71: 104-11. [PubMed]

Lehrer, Keith. 1990. Theory of Knowledge. Boulder: Westview Press Inc.

Lennon, Alexia, and Andrew Wollin. 2001. Learning Organizations: Empirically Investigating Metaphors. Journal of Intellectual Capital 2: 410-22. [CrossRef]

Liebowitz, Jay. 2001a. Knowledge Management and Its Link to Artificial Intelligence. Expert Systems with Applications 20: 1-6. [CrossRef]

Liebowitz, Jay. 2001b. If You Are a Dog Lover, Build Expert Systems; If You Are a Cat Lover, Build Neural Networks. Expert Systems with Applications 21: 63. [CrossRef] 
Linowes, Richard G., Tomasz Mroczkowski, Keikio Uchida, and Akira Komatsu. 2000. Using Mental Maps to Highlight Cultural Differences, Visual Portraits of American and Japanese Patterns of Thinking. Journal of International Management 6: 71-100. [CrossRef]

Malhotra, Yogesh. 2000. Knowledge Management for the New World of Business. Available online: http://www.brint.com/km/ whatis.htm (accessed on 10 April 2021).

Malhotra, Yogesh. 2001. Expert Systems for Knowledge Management: Crossing the Chasm Between Information Processing and Sense Making. Expert Systems with Applications 20: 7-16. [CrossRef]

Martensson, Maria. 2000. A Critical Review of Knowledge Management as a Management Tool. Journal of Knowledge Management 4: 204-16. [CrossRef]

Martinez, Michelle Neely. 1998. The Collective Power of Employee Knowledge. HR Magazine 43: 88-94.

Mayo, Andrew, and Elizabeth Lank. 1994. The Power of Learning, A Guide to Gaining Competitive Advantage. London: Institute of Personnel and Development.

Medsker, Larry, Margaret Tan, and Efraim Turban. 1995. Knowledge Acquisition from Multiple Experts: Problems and Issues. Expert Systems with Applications 9: 35-40. [CrossRef]

Morton, Adam. 2002. A Guide through the Theory of Knowledge. Hoboken: John Wiley \& Sons.

Mouck, Tom. 1998. Capital Markets Research and Real World Complexity: The Emerging Challenge of Chaos Theory. Accounting, Organizations and Society 23: 189-215. [CrossRef]

Mouritsen, Jan. 1998. Driving Growth: Economic Value Added versus Intellectual Capital. Management Accounting Research 9: 461-82. [CrossRef]

Narula, Rajneesh, and John H. Dunning. 1998. Explaining International R\&D Alliances and the Role of Governments. International Business Review 7: 377-97. [CrossRef]

Noh, Jermim B., Kunchang C. Lee, Jae-kyeong Kim, Jae-kwang Lee, and Sounghie H. Kim. 2000. A Case-Based Reasoning Approach to Cognitive Map-Driven Tacit Knowledge Management. Expert Systems with Applications 19: 249-59. [CrossRef]

Nonaka, Ikujiro, Ryoko Toyama, and Noboru Konno. 2000. SECI, Ba and Leadership: A Unified Model of Dynamic Knowledge Creation. Long Range Planning 33: 5-34. [CrossRef]

Nonaka, kujiro. 1991. The Knowledge-Creating Company. Harvard Business Review 6: 96-111.

Nonaka, Kujiro. 1994. A Dynamic Theory of Organizational Knowledge Creation. Organization Science 5: 14-37. [CrossRef]

Ntuen, Celestine A., and Jacqueline A. Chestnut. 1995. An Expert System for Selecting Manufacturing Workers for Training. Expert Systems with Applications 9: 309-32. [CrossRef]

Ohsuga, Setsuo. 1995. A Way of Designing Knowledge Based Systems. Knowledge-Based Systems 8: 211-22. [CrossRef]

Parker, Lee D. 2000. Goodbye, Number Cruncher. Australian CPA 70: 50-52. Available online: https://www.scirp.org/(S(i43dyn4 5teexjx455qlt3d2q))/reference/ReferencesPapers.aspx?ReferenceID=2250484 (accessed on 10 April 2021).

Petty, Richard, and James Guthrie. 2000. The Case for Reporting on Intellectual Capital: Evidence, Analysis and Future Trends. In The Current State of Business Disciplines, Volume 1, Accounting. Edited by Shri Bhagwan Dahiya. Rohtak: Spellbound Publications.

Power, Michael. 2001. Imagining, Measuring and Managing Intangibles. Accounting, Organizations and Society 26: 691-93. [CrossRef]

Quintas, Paul, Paul Lefrere, and Geoff Jones. 1997. Knowledge Management: A Strategic Agenda. Long Range Planning 30: 385-91. [CrossRef]

Ragothaman, Srinivasan, Jon Carpenter, and Thomas Buttars. 1995. Using Rule Induction for Knowledge Acquisition: An Expert Systems Approach to Evaluating Material Errors and Irregularities. Expert Systems with Applications 9: 483-90. [CrossRef]

Richards, Ian, David Foster, and Ruth Morgan. 1998. Brand Knowledge Management: Growing Brand Equity. Journal of Knowledge Management 2: 47-54. [CrossRef]

Romer, Paul M. 1998a. Bank of America Roundtable on the Soft Revolution: Achieving Growth by Managing Intangibles. Journal of Applied Corporate Finance 11: 8-27. [CrossRef]

Romer, Paul M. 1998b. Two Strategies for Economic Development: Using Ideas and Producing Ideas. In The Strategic Management of Intellectual Capital. Edited by David A. Klein. Woburn: Butterworth-Heinemann.

Ronen, Joshua. 2001. On R\&D Capitalization and Value Relevance: A Commentary. Journal of Accounting and Public Policy 20: 241-54. [CrossRef]

Roos, Goran, and Johan Roos. 1997. Measuring Your Company's Intellectual Performance. Long Range Planning 30: 413-26. [CrossRef]

Roos, Johan, Leif Edvinsson, and Nicola C Dragonetti. 1997. Intellectual Capital, Navigating the New Business Landscape. London: Macmillan Business.

Roos, Johan. 1998. Exploring the Concept of Intellectual Capital (IC). Long Range Planning 31: 150-53. [CrossRef]

Rose, Jacob M., and Christopher J. Wolfe. 2000. The Effects of System Design Alternatives on the Acquisition of Tax Knowledge from a Conceptualized Tax Decision Aid. Accounting, Organizations and Society 25: 285-306. [CrossRef]

Rowley, Jennifer. 1999. What Is Knowledge Management? Library Management 20: 416-19. [CrossRef]

Sadler-Smith, Eugene, David P. Spicer, and Ian Chaston. 2001. Learning Orientations and Growth in Smaller Firms. Long Range Planning 34: 139-58. [CrossRef]

Schaefer, Mary. 1998. Eight Things Communicators Should Know and Do About Knowledge Management. Communication World 15: 26.

Senge, Peter M. 1990. The Fifth Discipline: The Art and Practice of the Learning Organisation. New York: Doubleday. 
Stalk, George, Jr., Philip Evans, and Lawrence E. Shulman. 1992. Competing on Capabilities: The New Rules of Corporate Strategy. Harvard Business Review 2: 57-69.

Stolowy, Harve, and Anne Jenny-Cazavan. 2001. International Accounting Disharmony: The Case of Intangibles. Accounting, Auditing $\mathcal{E}$ Accountability Journal 14: 477-96. [CrossRef]

Stonehouse, George H., Jonathan D. Pemberton, and Claire E. Barber. 2001. The Role of Knowledge Facilitators and Inhibitors: Lessons from Airline Reservations Systems. Long Range Planning 34: 115-38. [CrossRef]

Studer, Rudi, V. Richard Benjamins, and Deter Fensel. 1998. Knowledge Engineering: Principles and methods. Data $\mathcal{E}$ Knowledge Engineering 25: 161-97. [CrossRef]

Sveiby, Karl Erik. 1997. The New Organizational Wealth, Managing \& Measuring Knowledge Based Assets, 5th ed. San Francisco: Barrett-Koehler.

Sveiby, Karl Erik. 1998. Measuring Intangibles and Intellectual Capital: An Emerging First Standard. Available online: https: //www.sveiby.com/archives/articles/1998 (accessed on 11 April 2021).

Taylor, W. Andrew, D. H. Weimann, and Peter J. Martin. 1995. Knowledge Acquisition and Synthesis in a Multiple Source Multiple Domain Process Context. Expert Systems with Applications 8: 295-302. [CrossRef]

Teece, David J. 2000. Strategies for Managing Knowledge Assets: The Role of Firm Structure and Industrial Context. Long Range Planning 33: 35-54. [CrossRef]

Teegen, Hildy. 2000. Examining Strategic and Economic Development Implications of Globalising Through Franchising. International Business Review 9: 497-521. [CrossRef]

The Economist Intelligence Unit. 1998. Knowledge Workers Revealed, New Challenges for Asia. Researched and Written with Andersen Consulting. Hong Kong: The Economist Intelligence Unit.

Thompson, Kevin. 1999. Emotional Capital. Oxford: Capstone Publishing.

Tissen, Rene, Daniel Andriessen, and Frank Lopez. 2000. The Knowledge Dividend, Creating High-Performance Companies through Value-Based Knowledge Management. Harlow: Pearson Education.

Tollington, Tony. 2001. UK Brand Asset Recognition Beyond “Transactions or Events”. Long Range Planning 34: 463-87. [CrossRef]

Van der Meer-Kooistra, Jeltje, and Siebre M. Zijlstra. 2001. Reporting on Intellectual Capital. Accounting, Auditing E Accountability Journal 14: 456-76.

Van Wegen, Bert, and Robert de Hoog. 1999. Impacts of Knowledge Based Systems: Beyond Anecdotes and Checklists. Expert Systems with Applications 16: 197-219. [CrossRef]

Vanoirbeek, Christine, Yassine Aziz Rekik, Nikos Karacapilidis, Omar. Abou Khaled, Norbert Ebel, and John-Paul Vader. 2000. A Web-Based Information and Decision Support System for Appropriateness in Medicine. Knowledge-Based Systems 13: 11-19. Available online: https:/ / dl.acm.org/doi/abs/10.1016/S0950-7051(99)00052-0 (accessed on 11 April 2021). [CrossRef]

Von Krogh, Gorg, Ikujiro Nonaka, and Manfred Aben. 2001. Making the Most of Your Company's Knowledge: A Strategic Framework. Long Range Planning 34: 421-39. [CrossRef]

Walczak, Steven. 1998. Knowledge Acquisition and Knowledge Representation with Class: The Object-Oriented Paradigm. Expert Systems with Applications 15: 235-44. [CrossRef]

Wallace, James S. 1996. Adopting Residual Income-Based Compensation Plans: Do You Get What You Pay For? Journal of Accounting $\mathcal{E}$ Economics 24: 275-300. [CrossRef]

Welbourne, Michael. 2014. Knowledge. New York: Routledge.

Wiig, Karl M. 1993. Knowledge Management Foundations: Thinking About Thinking: How People and Organizations Represent, Create and Use Knowledge. Arlington: Knowledge Research Institute, Schema Press.

Wiig, Karl M. 1997. Knowledge Management: Where Did It Come from and Where Will It Go? Expert Systems with Applications 13: 1-14. [CrossRef]

Wiig, Karl M., Robert De Hoog, and Rob Van der Spek. 1997. Supporting Knowledge Management: A Selection of Methods and Techniques. Expert Systems with Applications 13: 15-27. [CrossRef]

Wong, Kuan Yew, and Elaine Aspinwall. 2005. An Empirical Study of the Important Factors for Knowledge-Management Adoption in the SME Sector. Journal of Knowledge Management 9: 64-82. [CrossRef]

Wooten, Thomas C., and Thomas H. Rowley. 1995. Using Anthropological Interview Strategies to Enhance Knowledge Acquisition. Expert Systems with Applications 9: 469-82. [CrossRef]

Young, David. 1997. Economic Value Added: A Primer for European Managers. European Management Journal 15: 335-43. [CrossRef]

Zambon, Stephano, and Luca Zan. 2000. Accounting Relativism: The Unstable Relationship Between Income Measurement and Theories of the Firm. Accounting, Organizations and Society 25: 799-822. [CrossRef]

\section{Short Biography of the Author}

Indra Abeysekera is Professor of Accounting and Chair of Accounting and Finance at Charles Darwin University, Australia. Professor Abeysekera has published over a decade of peer-reviewed scholarly materials. 